\title{
Just one more rash?
}

\author{
Susana Alexandre, Ana Rita Constante, ${ }^{\ominus}$ Zulmira Abdula, Sara Santos
}

Pediatrics, Centro Hospitalar do Oeste, Caldas da Rainha, Portugal

\section{Correspondence to}

Dr Ana Rita Constante ana.rconstante@gmail.com

Accepted 4 February 2019

\section{DESCRIPTION}

We present the case of a healthy 2-year-old boy, who showed decreased appetite, abdominal pain and diarrhoea for 2 weeks with spontaneous resolution. About 1 week later, he developed exanthematous lesions symmetrically distributed in the limbs (figures 1 and 2). Personal or family history was irrelevant. His last vaccination was 6 months before, with the pentavalent vaccine. There was no history of fever, pruritus or other symptoms. Physical examination showed a monomorphic symmetrical papular exanthema, with lesions from 1 to $10 \mathrm{~mm}$ in diameter and with an acral distribution, sparing both palms and soles.

Given the characteristic clinical presentation, the diagnosis of Gianotti-Crosti syndrome (GCS) was assumed.

In a 10-day reassessment visit, the mother mentioned persistence of the skin lesions associated with asthenia, so we opted for simple laboratory evaluation that revealed a normal blood count and slightly elevated sedimentation rate $(35 \mathrm{~mm} /$ hour $)$

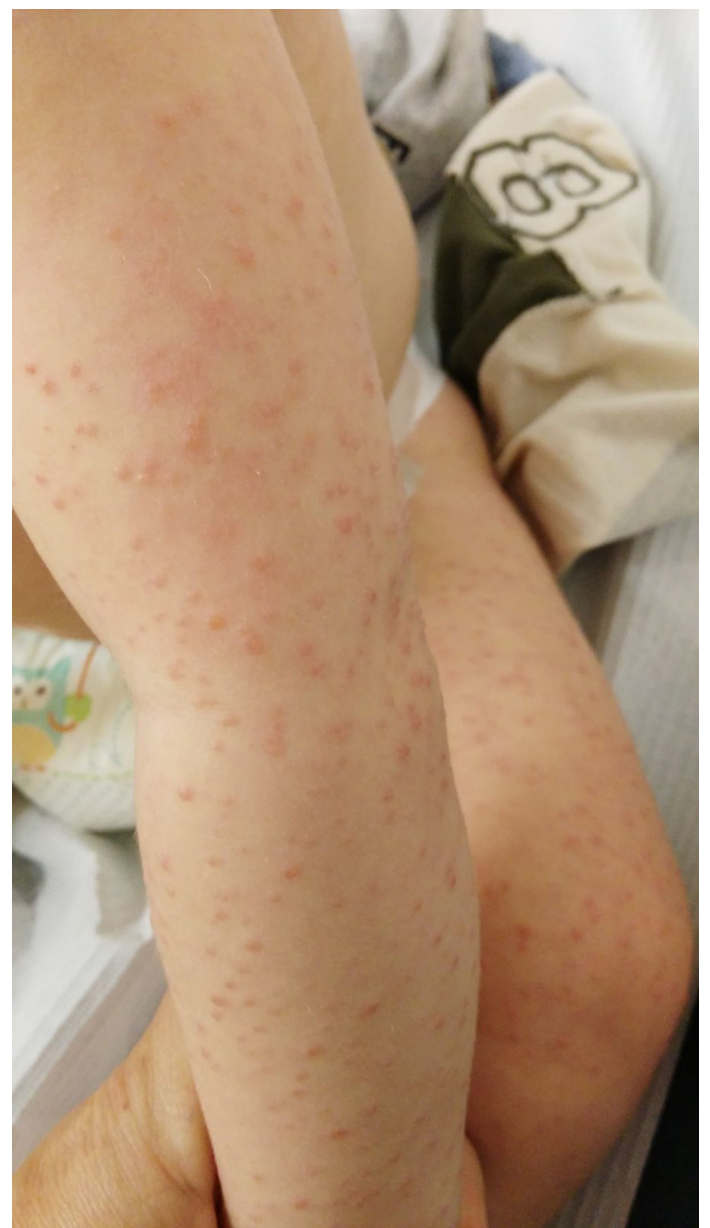

Figure 1 Skin lesions on the arms. and transaminases (Aspartate transaminase (AST) $53 \mathrm{IU} / \mathrm{L}$, Alanine transaminase (ALT) $65 \mathrm{IU} / \mathrm{L}$ ). Serologies for herpes type- 6 showed late infection (IgM negative and IgG positive) and were negative for hepatitis $\mathrm{A}$ and $\mathrm{C}$ viruses, cytomegalovirus and Epstein-Barr virus. A dermatology consult was asked for and the diagnosis was confirmed. No intercurrences or sequels were documented so far.

Exanthematic diseases are a common cause of paediatric emergency department visits. Although most patients require only symptomatic management, it is important to be aware of specific syndromes that may have future implications and are often underdiagnosed.

The pathogenesis of GCS, also popularly known as acrodermatitis, is a distinctive eruption that predominantly occurs in children younger than 5 years old about 1 week after a viral illness (usually respiratory or gastrointestinal disease). ${ }^{1}$

The incidence and prevalence of GCS are unknown. Because many children with GCS may be

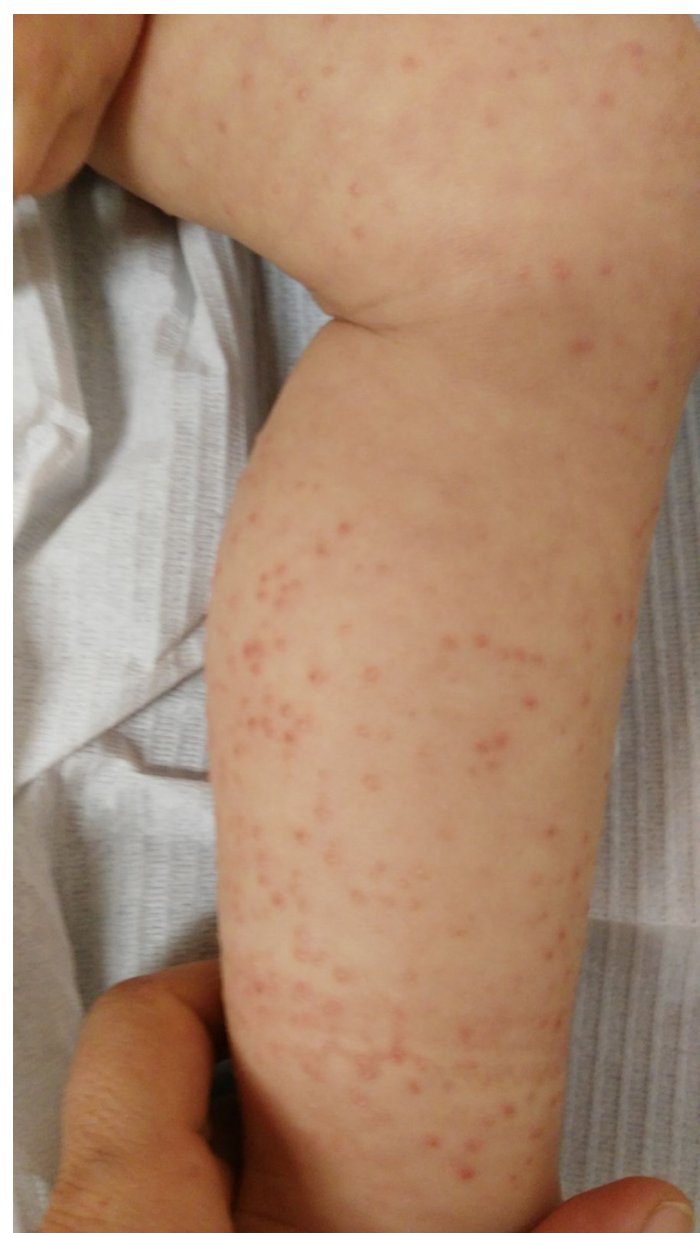

Figure 2 Skin lesions on the legs. 
diagnosed with a 'viral rash' or 'non-specific viral exanthem', it is probably underdiagnosed. ${ }^{2}$

Diagnostics that may be confused with GCS include erythema infectiosum or other viral exanthems, erythema multiforme, hand-foot-mouth disease, papular urticaria and cutaneous drug eruptions. Less common but important conditions to consider in the differential diagnosis, because of the different implications for treatment, prognosis and spread of infection, include papular purpuric gloves and socks syndrome, acrodermatitis enteropathica, immunoglobulin A vasculitis, and Kawasaki disease.

Clinical features that may help in differential diagnosis are the onset, duration, distribution and colour of the rash, and the presence and intensity of pruritus.

GCS is characterised by papular erythematous dermatitis with acral distribution and may be associated with lymphadenopathy

\section{Learning points}

- Gianotti-Crosti Syndrome is probably underdiagnosed since it can be easily mistaken for another exanthematic disease.

- It usually presents with a benign and self-limited course, with no need for specific therapy.

- It is important to recognise this syndrome because the skin lesions can take several months to clear off, raising unnecessary worry and investigation. and anicteric acute hepatitis. In most cases, it has spontaneous remission of the skin lesions. If liver involvement is present, follow-up is advised because of an increased risk of progression to chronic liver disease. ${ }^{2}$

The diagnosis of GCS is clinical, with no confirmatory tests, so it is important to recognise this entity as it may present with a prolonged course, leading to unnecessary concerns and investigation. The erythematous papules may coalesce into plaques and persist for 15-50 days. The lesions resolve spontaneously, thus requiring no treatment. If present, pruritus may be relieved by emollients or calamine lotion. ${ }^{1}$

Contributors Identified and managed the case: SS. Idea for the article: SA Performed the literature search: SA, ARC. Wrote the article: SA. Reviewed the article: ARC, ZA, SS. Guarantor: SA

Funding The authors have not declared a specific grant for this research from any funding agency in the public, commercial or not-for-profit sectors.

Competing interests None declared.

Patient consent for publication Parental/guardian consent obtained.

Provenance and peer review Not commissioned; externally peer reviewed.

\section{REFERENCES}

1 Kliegman RM, Stanton BF, Geme JW, et al. Nelson Textbook of Pediatrics. 20th edn. Philadelphia: Elsevier. 2016:3167-8.

2 Chuh AA. Gianotti-Crosti syndrome (papular acrodermatitis). UpToDate [Internet]. 2017. https://www.uptodate.com/contents/gianotti-crostisyndrome-papularacrodermatitis (cited Mar 2018).

Copyright 2019 BMJ Publishing Group. All rights reserved. For permission to reuse any of this content visit https://www.bmj.com/company/products-services/rights-and-licensing/permissions/

BMJ Case Report Fellows may re-use this article for personal use and teaching without any further permission.

Become a Fellow of BMJ Case Reports today and you can:

- Submit as many cases as you like

- Enjoy fast sympathetic peer review and rapid publication of accepted articles

- Access all the published articles

- Re-use any of the published material for personal use and teaching without further permission

For information on Institutional Fellowships contact consortiasales@bmjgroup.com

Visit casereports.bmj.com for more articles like this and to become a Fellow 